\title{
COMMUNICABLE DISEASES AMONG THE FEMALE INHABITANTS OF LOWER SOCIO-ECONOMIC GROUPS IN DHAKA CITY
}

\author{
Mst. Tahmina Karim, Hamida Khanum and Sharmin Musa \\ Department of Zoology, Faculty of Biological Sciences, University of Dhaka \\ Dhaka 1000, Bangladesh
}

\begin{abstract}
A total of 900 female inhabitants of lower socioeconomic in Dhaka city, were examined during September, 2013 to August, 2015. Among them, the prevalence of gastrointestinal parasitic infestation was $66.22 \%$. The prevalence of Urinary tract infection (UTI) was $31.44 \%$. Among the female inhabitants, $41.33 \%$ were infected with different types of skin diseases; within these, viral, (19.35\%) scabies and $38.09 \%$ were affected by boil disease. The prevalence of vector-borne diseases was infected and arthropod infections (9.41\%) were found. Among them, the highest $54.28 \%$ were infected by scabies and $38.09 \%$ were affected by boil diseases. The prevalence of vector-borne diseases was $49.33 \%$, among them four types of diseases were recorded of which $2 \%$ malaria, $7.33 \%$ filaria, $34.67 \%$ dengue and $5.33 \%$. leishmaniasis. Four types of waterborne diseases were found such as cholera/ diarrhoea (28\%), typhoid (17.11\%), polio $(5.11 \%)$ and hepatitis A/ Jaundice (9.67\%); and overall prevalence was $59.87 \%$. Regarding the airborne diseases, $58.44 \%$ were found to be infected, among them four types recorded, such as influenza (25.11\%), mumps (10.22\%), pneumonia (17.44\%) and tuberculosis $(5.67 \%)$.
\end{abstract}

Key Words: Communicable diseases, lower socioeconomic groups, female and Dhaka city.

\section{INTRODUCTION}

The communicable diseases are illness that usually transmit through contact of pathogenic organisms. Human, animals, water and foods are all carriers of organisms that can transfer an infectious agent from infected host to another (Smith 2012). Communicable diseases are caused by pathogenic organisms such as bacteria, viruses, fungi and parasites. The agents are directly transfer from one infected person to another or from an animal to a

Author for corresponding: <hamida_khanum@yahoo.com>

(C2020 Zoological Society of Bangladesh DOI: :https://doi.org/10.3329/bjz.v48i1.47880 
human or from some inanimate object to an individual. Some communicable diseases can spread in more than one way, such as, by consuming contaminated foods or beverages, contact with contaminated body fluids, air borne (inhalation), water or being bitten by an infected animal, insect or tick (http://langladecountyhealth.org/communicable-disease/).

Communicable diseases are several contagious like water borne disease (cholera, typhoid fever etc.); vector borne diseases (malaria, dengue, yellow fever etc.); associated with overcrowding (tuberculosis, diarrhoeal diseases etc.); vaccine preventable diseases (polio, tetanus etc.) airborne diseases (pneumonia, influenza etc.).

In Southeast Asia, intestinal parasitic diseases are a major public health problem particularly among poor children living in urban squats and rural communities (Bundy et al. 1992, Chan 1997). The parasites affect physical growth and psychomotor development in the infected children (Oberhelman et al. 1998; WHO 1981). In some parts of Bangladesh, the prevalence of enteric parasites is $80 \%$ (Khan et al. 1986). Geohelminths are readily transfer to human via the oro-faecal route, either directly, through contact with contaminated hands, or indirectly, via contamination of food, water, or the environment. Proper hygiene and sanitation, proper dispersal of faeces in the environment can reduce the infection and thus interrupt the transmission of oro-faecal infections (Feachem et al. 1983).

Urinary tract infection (UTI) is the second most common infection in the community. UTI develop due to the presence of multiplying micro-organism in the urinary tract including urinary bladder, prostate, kidney, ureters and urethra (Hackett 2005, Simon 2006). The syndrome ranges from asymptomatic bacteriuria to perinephric abscess with sepsis (Johnson 1991). The most significant danger to urinary tract infections is that they can affect the kidney (causing pyelonephritis) and develop bladder infections (cystitis) subsequently (Nahar et al. 2010). Approximately, forty percent of children and adult women will experience symptoms of cystitis during their lifetime and their possible risk that a repeated symptomatic episode will occur within 6-12 months (Foxman 1990). Acute UTI occurs each year in many women in Bangladesh and 20-30\% suffers from recurring infections (Patton et al. 1991).

Skin and venereal diseases cause a large part of illness. About $30 \%$ of people in Bangladesh suffer from it in their life time. Recurrence, excessive use of chemicals and cosmetics, environmental pollution, delayed marriage etc are the major leading factors for the initiation and transmission of the diseases (Rahman et al.1997). Several types of bacterial and fungal infections are found which may causes chronic course and sufferings. Prevalence increases in overcrowded population and facilities for daily washing the body and clothing 
are reduced. Bangladesh is known to have a high prevalence of skin diseases as directed by Directorate General Health Services (DGHS) (Anowar et al. 2001)

Nearly half of the world's population is infected by vector-borne diseases, resulting in high morbidity and mortality. The distribution of the incidence of vector-borne diseases is grossly disproportionate, with the overwhelming impact in developing countries located in tropical and subtropical areas (Ciesin 1994). A vector-borne disease are the pathogenic microorganisms, transmitted from an infected individual to another by an arthropod or other agent serving as intermediary hosts. The transmission depends upon the attributes and requirements of at least three different living organisms: the pathogenic agent, either a virus, protozoa, bacteria or helminth (worm), the vector, which are commonly arthropods such as ticks or mosquitoes. In addition, intermediary hosts such as domesticated or wild animals often serve as a reservoir for the pathogens until susceptible human populations are exposed (http://ciesin.columbia.edu/TG/HH.v-bd.html).

Malaria is one of the most devastating diseases of the world (WHO 2005). The magnitude of malaria in terms of morbidity and mortality in human makes it a major public health problem in the tropical and subtropical countries (Farooq et al. 2006). Lymphatic filariasis (LF) is one of the most disfiguring diseases and a major cause of clinical morbidity. It is the world's second leading cause of permanent disability and a major impediment to socioeconomic development (WHO 2002, Dreyer et al. 1997). Over the past four decades, dengue disease has become recognized as the world's most important mosquitoborne viral disease, emerging in countries previously considered free of disease and re-emerging in countries where the disease was once controlled (Gubler 1998, Ooi and Gubler 2009). Leishmaniasis is also a chronic inflammatory disease of the skin, mucous membrane, or viscera caused by obligate intracellular, kinetoplastoid protozoan parasites Leishmania, transmitted through the bite of infected sand-fly (Kumar et al. 2004).

Water borne parasitic infections are common worldwide due to the shortage of drinking water, and unhygienic conditions of storage and manipulation of contaminated water in different daily purposes (WHO 1991). Increased human consumption and pollution have caused a shortage of fresh water resources worldwide (Caccio et al. 2003, Parvez et al. 2007). Drinking water contamination has devastating effects on the health of human society and implies the presence of microorganisms which could potentially create water-borne particularly those with impaired immune systems (Steiner et al. 1997). Polluted and contaminated water can cause waterborne diseases like diarrhoea, cholera, typhoid fever and dysentery. About 2 million deaths per year were reported worldwide due to unsafe water, mostly due to waterborne, preventable diarrhoeal diseases (Elimelech 2006). 
There are hundreds of air borne communicable pathogens (Beggs 2003, Tang et al. 2006, Kowalski and Bahnfleth 1998) falling into three major categories: viruses, bacteria, and fungal spores. Human-human transmission of disease can result from direct contact with an infected person or an indirect contact through an intermediate object (Beggs 2003). An important mode of indirect contact is air borne transmission occurring via the spread of fine aerosols, skin flakes, and fungal spores in room air over long distances and time scales (Morawska 2006). The transmission of infectious disease is of global concern for social and economic reasons. Seasonal influenza kills 200-500 thousand people annually. In 2009-2010, influenza A (H1N1) caused 17,000 deaths worldwide, many among whom were healthy adults (Tellier 2009, Wan et al. 2009).

\section{MATERIAL AND METHODS}

The present investigation was a cross sectional and descriptive study, conducted during the period of September 2013 to August 2015 among the female inhabitants of lower socioeconomic groups in twelve areas of Dhaka city. Nine hundred (900) female inhabitants of different age groups were taken as respondents for the present research work. Urine and stool samples were collected from each individual and were examined in laboratory. Intestinal parasitic infections were identified by examining the faecal samples. Fecal samples were analyzed by formol-ether concentration technique. Urinary tract infection (UTI) was identified by examining the urine samples through sedimentation technique, culture and sensitivity test. The skin, vector-borne, water borne and air borne diseases were identified by observing at the sign, symptoms and previous history of the diseases. The prevalence rate was showed by calculating percentage of infestations. Tables and graphs were prepared using MS Word and MS Excel software's and results were analyzed by statistical test. Statistical analysis was carried out by using Statistical Package for Social Science (SPSS) using F-test.

\section{RESULTS AND DISCUSSION}

During the present investigation, out of 900 stool samples 596 (66.22\%) female were found infected with intestinal parasites. The prevalence of intestinal parasites were found highest because of slum areas where hygienic conditions are not maintain properly and not conscious about personal hygiene. The present result were lower than the findings of Suguti et al. (1985) in Nepalese people (86.8\%) and Uddin and Khanum (2008) in Comilla and Dhaka (84.21\%). Alternatively the present prevalence was higher than the findings of Ahmed and Hady (1989) in Riyadh, Saudi Arabia (10.94\%), Al-Madani and Mahfouz (1995) in Aba District, Saudi Arabia (46.5\%) and Peruzzi et al. (2006) in Italy (13.24\%). 
The cause behind the contradiction might be the geographical differences, differences in study population, different socio- economic conditions and gender majority. Chowdhury (1978) found $52.76 \%$ prevalence in the people of Dhaka, $53 \%$ of the Yemini people (Farag (1985), 62\% from the people of southwest Nigeria (Reinthaler et al. (1988), 51.7\% in China (Tang and Luo (2003), 50.5\% in Nigeria (Ikeh et al. (2006), which were closely related with present findings.

Out of the 900 urine samples of females, $31.44 \%$ prevalence of UTI was recorded. Leblebicioglu and Esen (2001) reported 1.7\%, Begum et al. (2006) found $16.4 \%$ and Almushait et al. (2013) observed $12.7 \%$ were affected with UTI, these findings were lower than present study. According to Moue et al. (2015), prevalence rate of infection of urinary pathogen was $79.5 \%$; Mazed et al. (2008) demonstrated that the rate of UTI was $48.61 \%$ that was higher than present study. Similar study by Kattel et al. (2008), in which $26 \%$ of urine specimens showed significant bacterial growth and Wagenlehner et al. (2006) from Germany reported that the incidence of nosocomial UTI was $28 \%$.

Regarding the skin diseases, 372 (41.33\%) were infected with different types of skin diseases, among them $168(45.16 \%)$ were infected with bacteria, 97 $(26.07 \%)$ were with fungus, $72(19.35 \%)$ with virus and $35(9.41 \%)$ with arthropod/ ectoparasite (Fig 1). Bahamden et al. (1995) found 19.8\% children in Saudi Arabia were affected by transmissible skin diseases, Basit (1996) reported $1.5 \%$ in East Pakistan, Saw et al. (2001) showed 28\% in Sumatra, Indonesia. Above findings were lower than present study. A similar study was conducted by Kiprono et al. (2015), where among the 152 infectious skin diseases, fungal infections predominated $50.7 \%$ followed by bacterial $29.6 \%$ and viral $19.7 \%$. ElKhateeb et al. (2014) observed 5.9\% bacterial infections in Damietta, Egypt and this was very lower than present study. Hossain (1993) observed $20.91 \%$ fungal infection, Mridula et al. (2015) found 21.6\%, and these results were near to present study. Anand and Gupta (1998) observed $13.51 \%$ fungal infected patients which were lower than present finding. Rahman et al. (1997) found 2\% viral infection, Hossain (1993) found $7.50 \%$ and both were lower than the present results. Parthasaradhi and Al Gufai (1998) recorded $12.80 \%$ viral infections that were near to present finding. According to Arun et al. (2014), $56.25 \%$ viral infections were found which was much higher than present observation.

Among the 900 female inhabitants, 49.33\% were found to be infected by four types of vector-borne diseases such as malaria (2\%), filaria $(7.33 \%)$, dengue $(34.67 \%)$ and leishmaniasis/ kala-azar (5.33\%) (Fig 2). In Dhaka city malarial and filarial patients were found mainly those coming for treatment purpose or 
carry the infection from endemic district and spread the diseases in areas. Faruque et al. (2012) confirmed $0.56 \%$ malaria patients on febrile patients which were lower than present findings. Koltas et al. (1999) reported 40\% at Cukurova region of Turkey and Agomo et al. (2009) reported 7.7\% in Nigeria. Above results were higher than present observation. Barry et al. (1971) found that filarial disease rate $10.1 \%$. Go (1993) described that in Marinduque of Philippines microfilaria rate were $16 \%$. Rahman et al. (2008) observed disease rate were $21.1 \%$. Above findings were higher than the present study. Eigege et al. (2002) reported prevalence rates ranging from $6 \%-47 \%$ in Nigeria which was close to present study. Daniel et al. (2005) found 66.4\% dengue fever patient while Zaman et al. (2014) found 54\% prevalence in female and both results were higher than present study. Faruque et al. (2012) found, 9.6\% were positive for dengue virus which was lower than present finding. Shanmugham et al. (1977) reported 50.35\% prevalence of kala-azar in Madras, Ali and Ashford (1993) observed 36.4\% in Ethiopia and Shiddo et al. (1995) found 26\% in Somalia, all were much higher than the present findings.

In the present investigation, $59.87 \%$ were found to be infected by four types of water borne diseases such as cholera/ diarrhoea (28\%), typhoid (17.11\%), polio (5.11\%) and hepatitis A/ jaundice (9.67\%) (Fig 3). Sedhain (2014) found $50.7 \%$ prevalence of water borne diseases in Nepal. Present study showed approximate similarity with this result but little higher than this. Alajo et al. (2006) found $52 \%$ cholera patients, this result was higher than the present study, Poulos et al. (2011) reported 22-38\% of cholera patients in Jakarta, Indonesia and Kolkata, India which was near to present studies result.

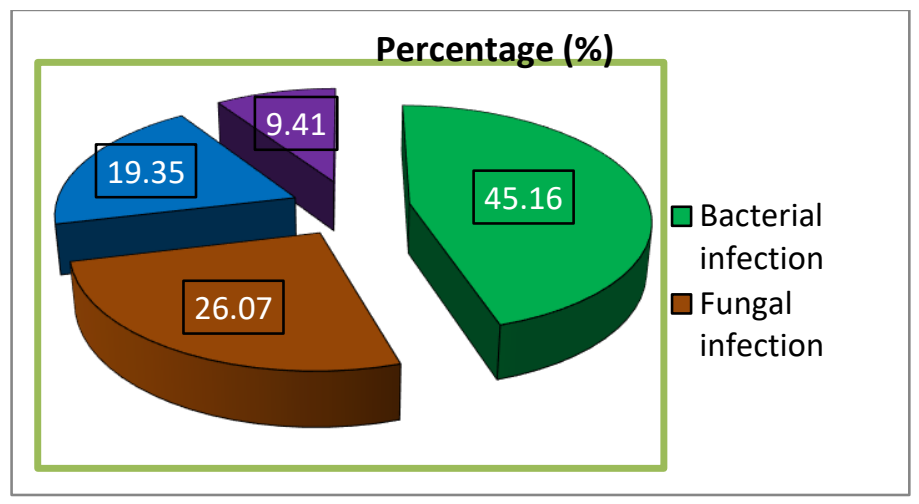

Fig 1. Prevalence of skin infections in female inhabitants. 


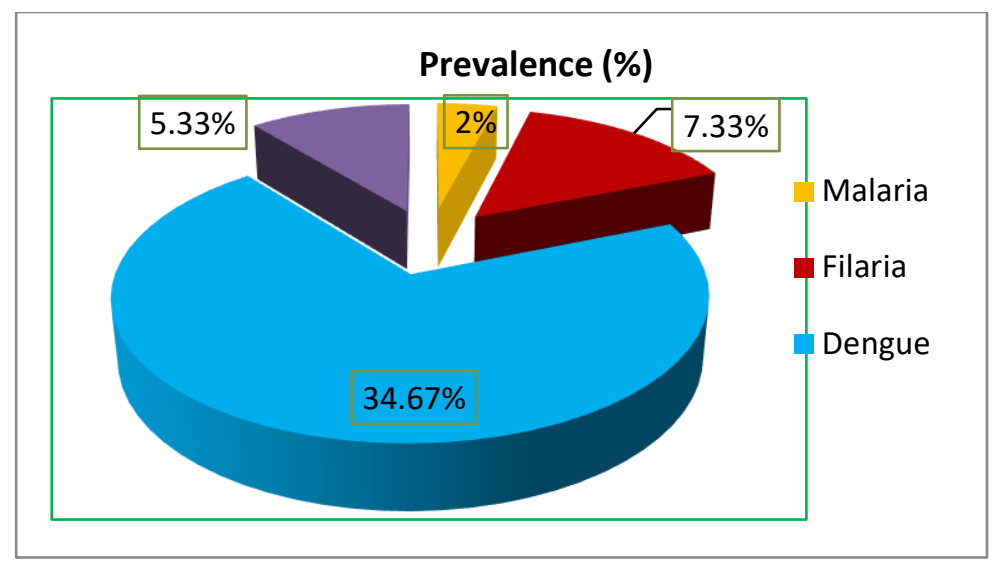

Fig 2.Prevalence of vector borne diseases found among female inhabitants.

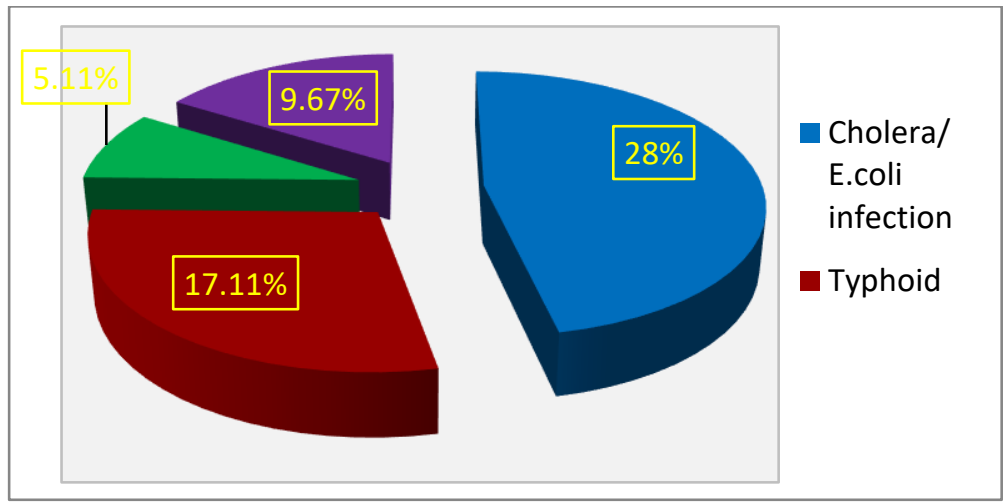

Fig 3. Prevalence of water borne diseases recorded among the female inhabitants.

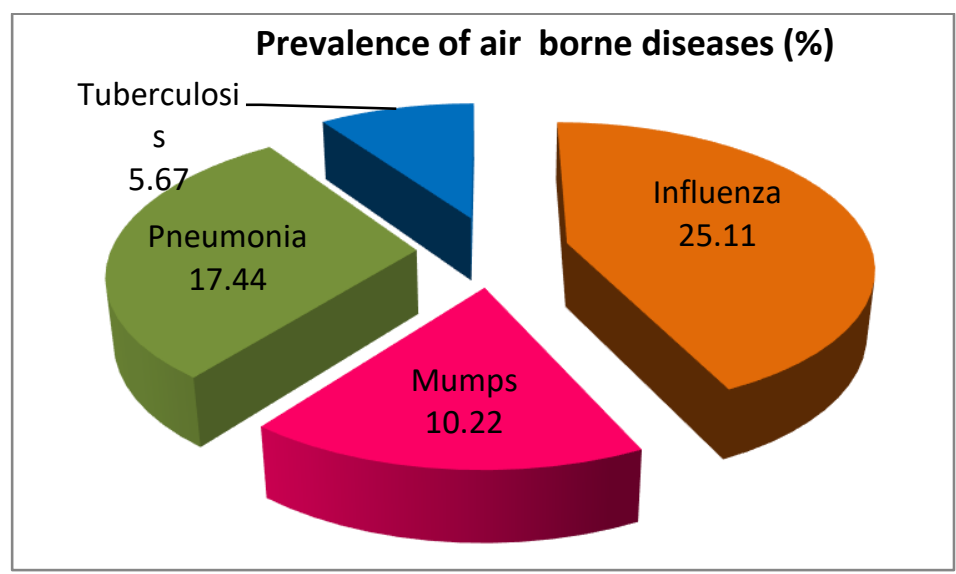

Fig 4. Air borne diseases found among the female inhabitants. 
According to Sun et al. (2013) prevalence of typhoid fever was $54.36 \%$ that was so much higher than the present finding. According to CDC (1998), 71.4\% polio have been confirmed in Bangladesh. Yu et al. (2012) found hepatocellular jaundice accounts for $59.72 \%$, viral hepatitis $31.94 \%$ which was so much higher than present observations.

In the present investigation, total $58.44 \%$ were found to be infected by four types of air borne diseases such as influenza (25.11\%), mumps (10.22\%), pneumonia (17.44\%) and tuberculosis (TB) (5.67\%) (Fig 4). Islam et al. (2012) found $9.1 \%$ prevalence on influenza which was lower than the present study. According to Kutty et al. (2014), 13\% developed mumps found in a highly vaccinated population in Orange County, New York, which was close to present finding. Saha et al. (2016) observed 61\% severe pneumonia in Bangladeshi children. Hashemi et al. (2014) worked on prevalence of tuberculosis and recorded $38 \%$ positive tuberculin test. Above two results were found much higher than the present study records.

\section{CONCLUSION}

Dhaka city is expanding rapidly but, in some areas, remains in unhygienic condition. Although the rate of parasitic infection is relatively high, possibly because of the large influx of villagers from rural areas to dwell in the city, poor knowledge of personal hygiene and lower socio-economic stratum of these people. The incidence of communicable diseases are likely to be common. The results of the present study will help for planning the control of parasitic infections. Communicable Infections are transmitted by biotic and abiotic transports which continue to create a public health problem in developing countries. Communicable diseases are also report deaths among conflictaffected populations due to malnutrition and limited access to basic needs. Due to the lack of adequate sanitation and improper hygienic, infectious diseases are rampant in Bangladesh. Vaccination, either through scarification or preanaterial injection been shown to be effective in eliminating infectious diseases throughout the world.

\section{LITERATURE CITED}

AGOMO, C.O., OYIBO, W.A., ANORLU, R.I. and AGOMO, P.U. 2009. Prevalence of Malaria in Pregnant Women in Lagos, South-West Nigeria. Korean J Parasitol.47(2): 179-183.

AHMED, M.M. and EL HADY, H.M. 1989. A preliminary survey of parasitic infections and nutritional status among school children in Riyadh, Saudi Arabia. J Egypt Soc Parasitol. 19(1): 101105.

AL-MADANI, A.A. and MAHFOUZE, R.M. 1995. Prevalence of intestinal parasitic infections among Asian female housekeepers in Abha district, Saudi Arabia. SoutheastAsian J Trop Med Public Health. 26(1): 135- 137. 
ALAJO, S.O., NAKAVUMA, J. and ERUME, J. 2006. Cholera in endemic districts in Uganda during El Nino rains: 2002-2003. African Health Sciences. 6: 93-97.

ALI, A. and ASHFORD, R.W. 1993. Visceral leishmaniasis in Ethiopia. Cross-sectional Leishmanian skin test in an endemic locality. Ann Trop Med Parasitol. 87(2): 157-161.

ALMUSHAIT, M.A., MOHAMMED, H.A., AL-HARTHY, D.A. and ABDULLAH, A.M. 2013. Prevalence and Predisposing Factors of Urinary Tract Infections among Pregnant Women in Abha General Hospital. International Journal of Sciences: Basic and Applied Research (IJSBAR). 11(1): 18-29.

ANAND, I.S. and GUPTA, S. 1998. A profile of skin disorder in children in Saurashtra India. J Indian Med Assoc. 96(8): 245-246.

ANOWAR, N., KHAN, M.R., BAQI, M.A. and DEY, R.K. 2001 (eds). Bangladesh Health Bulletin 1998/1999. Unified Management Information System (UMIS). Directorate General Health Services (DGHS). October, 2001.

ARUN, G.R., DIVYASRI, R.A., SHAILAJA, U. and PRASANNA, N.R. 2014. A cross sectional observational epidemological study on the incidence of skin diseases among school children of urban area of southern India. Int $J$ Adv Res.2(1): 469-472.

BAHAMDEN, K., MAHFOUAZ, A.A. and TALLAP, T. 1995. Skin disease among boys in Abha Saudi Arabia, Inter J Dermatology. 35(6): 405-407.

BARRY, C., AHMED, A. and KHAN, A.Q. 1971. Endemic filariasis in Thakurgaon, East Pakistan. Am J Trop Med Hyg. 20: 592-597.

BASIT, A. 1996. A study of viral diseases in East Pakistan. Pakistan J Med Res. pp. 294-304.

BEGGS, C.B. 2003. The airborne transmission of infection in hospital buildings: fact or fiction? Indoor and Built Environment. 12(1-2): 9-18.

BEGUM, N., MAMOON, A.B.A, HOSSAIN, M., BEGUM, N., CHOWDHURY, S.A. and RAHMAN, F.A. 2006. UTI among female workers in a selected garment industry of Dhaka city: A cross sectional study. The Orion. 23: 325-327.

BUNDY, D.A.P., HALL, A., MEDLEY, G.F. and SAVIOLI, L. 1992. Evaluating measures to control intestinal parasitic infections. World Health Stat Q. 45: 168-79.

CACCIO, S.M., DE GIACOMO, M., AULICINO, F.A. and POZIO, E. 2003. Giardia Cysts in Wastewater Treatment Plants in Italy. Appl Environ Microbiol. 69(6): 3393-3398.

CDC. 1998. Progress toward poliomyelitis eradication - Bangladesh, 1995-97. MMWR. 47(02): 31-35.

CHAN, M.S. 1997. The global burden of intestinal nematodes infection - fifty years on. Parasitol Today. 12: 438-43.

CHOWDHURY, M.R. 1978. Intestinal parasite infection in privileged class of Dhaka population, Bangladesh. Armed Forces Med. J.4(1): 5-12.

CIESIN. 1994, Compiled by Meredith Golden, Information Scientist for Public Health.

DANIEL, R., RAJAMOHANAN, and PHILIP, A.Z. 2005. A study of clinical profile of dengue fever in Kollam, Kerala, India.Dengue Bulletin. 29: 197-202.

DREYER, G., NOROES, J., ROACH, A. and ADDISS, D.G. 1997. The silent burden of sexual disability associated with lymphatic filariasis. Acta Tropica.63:57-60.

EIGEGE, A., RICHARDS, F.O., BLANEY, D.D., MIRI, E.S., GONTOR, I., OGAH, G., UMARU, J., JANADU, M.Y., MATTHIAS, W., AMADIEGWU, S. and HOPKINS, D.R. 2002. Rapid assessment for lymphatic filariasis in central Nigeria: a Comparison of the Immunochromatographic card test and hydrocoele rates in an area of high endemicity. Am $J$ Trop Med Hyg. 68(6): 643-646.

ELIMELECH, M. 2006. The global challenge for adequate and safe water. Journal of Water Supply: Research and Technology - AQUA. 55: 3-10.

EL-KHATEEB, E.A., LOTFI, R.A., ABD ELAZIZ, K.M. and EL-SHIEKH, S.E. 2014. Prevalence of skin diseases among primary school children in Damietta, Egypt.Int J Dermatol.53(5): 609-16.

FARAG, H.F. 1985. Intestinal parasites in the populations of the Yemen Arab Republic. Trop Geogr Med.37: 29-31. 
FAROOQ, U., DUBEY, M.L., MALLA, N. and MAHAJAN, R.C. 2006. Plasmodium falciparum: Polymorphism in the MSP-1 Gene in Indian isolates and predominance of certain alleles in cerebral malaria. Expparasitol. 112: 139-143.

FARUQUE, L.I., ZAMAN, R.U., ALAMGIR,A.S.M. GURLEY, E.S., HAQUE, R., RAHMAN, M. and LUBY, S.P. 2012. Hospital-Based Prevalence of Malaria and Dengue in Febrile Patients in Bangladesh. Am J Trop Med Hyg. 86(1): 58-64.

FEACHEM, R.G., BRADLEY, D.J., GARELICK, H. and MARA, D.D. 1983. Sanitation and disease: health aspects of excreta and wastewater management. World Bank Studies in Water Supply and Sanitation 3. John Wiley and Sons Ltd, Chichester, UK. 501 pp.

FOXMAN, B. 1990. Recurring urinary tract infection: incidence and risk factors. Am $J$ Public Health.80: 331.

FOXMAN, B., BARLOW, R., D ARCHY, H., GILLESPIE, B. and SOBEL, J.D. 2000. Urinary tract infection: self-reported incidence and associated costs. Ann Epidemiol.10(8): 509-515.

GO, V.M. 1993. Lymphatic filariasis in a recently described endemic area in Marinduque, Philippines. Southeast Asian J Trop Med Public Health.2: 19-22.

GRIGORIU, D., DELSERETAZ, J. and BORELLI, D. 1987. Medical Mycology. Hans Hurber publisher. pp. 9-32.

GUBLER, D.J. 1998. Dengue and dengue hemorrhagic fever. Clin Microbiol Rev. 11:480-496.

HACKETT, G.2005. Urinary tract infection (UTI). Updated 2005 Oct [on the internet] Available from http://www.netdoctor.co.uk/menshealth/facts/urinaryinfection.htm.

HASHEMI, S.H., MAMANI, M., ALIZADEH, N., NAZARI, M. and SEDIGHI, I. 2014. Prevalence of tuberculosis infection among health-care workers in Hamadan, West of Iran. Avicenna $J$ Clin Microb Infec. 1(1): e19214.

HOSSAIN, M.M. 1993. Pattern of skin and sexually transmitted disease in district hospital. Bangladesh J Dermatol venerol leprol.10(2): 7-9.

http://ciesin.columbia.edu/TG/HH.v-bd.html

http:/ /langladecountyhealth.org/communicable-disease/

http://www.mindomo.com/mindmap/communicable-and-noncommunicable-diseases /

IKEH, E., OBADOFIN, M., BRINDERIO, B., BAUGHER, C., FROST, F., VANDERJAGT, D. and GLEW, R. 2006. Intestinal parasitism in rural and urban areas of North Central Nigeria: An update. Int $J$ Microbiol. 2(1): 1-5.

ISLAM, M.A., KHAN, M.K., BEG, A., AHMED, K.G.S. and ASADUZZAMAN, M. 2012. Surveillance of Influenza in outpatients ILI cases in community based medical college hospital, Bangladesh. C B M J. 1(2): 38-47.

JOHNSON, C.C. 1991. Defination, classification and clinical presentation of Urinary Tract infections. Med Clin North Am.75(2): 241-243.

KATTEL, H.P., ACHARYA, J., MISHRA, S.K., RIJAL, B.P. and POKHRE, B.M. 2008. Bacteriology of urinary tract infection among patients attending Tribhuvan university teaching hospital Kathmandu, Nepal. Journal of Nepal Association for Medical Laboratory Sciences. pp. 25-29.

KHAN, M., SHAHIDULLA, M., BAURA, D. and BEGUM, T. 1986. Efficacy of periodic deworming in urban slum population for parasitic control. Indian J Med Res.83: 82-88.

KIPRONO, S.K., MUCHUNU, J.W. and MASENGA, J.E. 2015. Skin diseases in pediatric patients attending a tertiary dermatology hospital in Northern Tanzania: a cross-sectional study. BMC Dermatology. 15:16.

KOLTAS, I.S., OZCAN, K., SERIN, M.S., KOKSAL, F. and AKSUNGUR, P. 1999. Cukurova Bolgesinde Plasmodium vivax Sitma Tanısinda Polimeraz Zincir Reaksiyonunun (Pcr) Kullanılmas1. Türk Parazitol Derg. 23 (2): 119-121.

KOWALSKI, W.J. and BAHNFLETH, W. 1998. Airborne respiratory diseases and mechanical systems for control of microbes, HPAC Heating, Piping, Air Conditioning. 70(7): 11

KUMAR, V., ABBAS, A.K. and FAUSTO, N. 2004, Robbins and Contran Pathologic basis of disease, 7th edn, Elsevier India private limited, New Delhi, India. 
KUTTY, P.K., MCLEAN, H.Q., LAWLER, J., SCHULTE, C., HUDSON, J.M. and BLOG, D. 2014.Risk factors for transmission of mumps in a highly vaccinated population in Orange County, NY, 2009-2010. Pediatr Infect Dis. J.33: 121-5.

LEBLEBICIOGLU, H. and ESEN, S. 2001. Nosocomial UTI in Turkey-a nationwide multicenter point prevalence study. Intersci Conf antimicrobial agent's chemother. 41: 6-9.

MAZED, M.A., HUSSAIN, A., AKTER, N., SULTAN, T. and DEWANJE, A.K. 2008. Pattern of bacteria causing urinary tract infections and their antibiotic susceptibility profile at Chittagong Medical College Hospital. Bangladesh J MedMicrobiol. 2(2): 17-21.

MORAWSKA, L. 2006. Droplet fate in indoor environments, or can we prevent the spread of infection? Indoor Air. 16(5): 335-347.

MOUE, A., AKTARUZZAMAN, S.A.Q.M., FERDOUS, N., KARIM, R., KHALIL, M.M.R. and DAS, A.K. 2015. Prevalence of urinary tract infection in both outpatient department and in patient department at a medical college setting of Bangladesh. International Journal of Biosciences. 7(5): 146-152.

MRIDULA, A.M., PUSHPALATHA, K. and GIRISH, M.S. 2015. Clinical spectrum of primary skin disorders in children less than 10 years.Journal of Evidence based Medicine and Healthcare.2(5): 505-512.

NAHAR, S.J., KHANUM, H. and SHIMASAKI, K. 2010. Occurrence of Escherichia coli infection among the women of Dhaka city. ARPN J Agri and Bio Sci.5(6): 68-73.

OBERHELMAN, R.A., GUERRERO, E.S., FERNANDEZ, M.L., SILIO, M., MERCADO, D., COMISKEY, N., IHENACHO, G. and MERA, R. 1998. Correlations between intestinal parasitosis, physical growth, and psychomotor development among infants and children from rural Nicaragua. Am JTrop Med Hyg.58: 470-475.

OOI, E.E. and GUBLER, D.J. 2009. Global spread of epidemic dengue: the influence of environmental change. Future Virol. 4:571 - 580.

PARTHASARADHI, A. and AL GUFAI, A.F. 1998. The pattern of skin diseases in Hail Region, Saudi Arabian. Ann Saudi Med. 18(6): 558-561.

PARVEZ, I.M., HUSSAIN, M.D. and ALI M.R. 2007. Present status of wastewater utilization in Bangladesh: A case study in Mymensingh periurban area. Agricultura Tropica Et Subtropica. 40(2): 65-70.

PATTON, J.P., NASH, D.B. and ABRUTYN, E. 1991. Urinary tract infection: economic considerations. Med Clin North Am. 75(2): 495-513.

PERUZZI, S., GORRINI, C., PICCOlO, G., CAlDERARO, A., DETTORI, G. and CHEZZI, C. 2006. Prevalence of intestinal parasites in the area of Parma during the year 2005. Acta Biomed. 77: $147-115$.

POULOS, C., RIEWPAIBOON, A., STEWART, J.F., CLEMENS, J. and GUH, S. 2011. Costs of Illness Due to Endemic Cholera. Epidemiology and Infection. 18: 1-10.

RAHMAN, M.S., ALAM, M.J., AWAL, M.A., ISLAM, R., BEGUM, M.P. and ISLAM, A.K.M.N. 1997. Pattern of skin diseases in skin and VD- OPD in Bogra Medical College and Mohammad Ali Hospital. J Bogra Med Coll.1(1): 9-11.

RAHMAN, A.B.M.M., KHANUM, H., CHOWDHURY, M. and FARHANA, R. 2008. Current status and endemicity of filariasis in Thakurgaon, northern part of Bangladesh. Bangladesh J Zool. 36(1): 111-116.

REINTHALER, F.F., MASCHER, F., KLEM, G. and SIXL, W. 1988. A survey of gastrointestinal parasites in Ogun State, southwest Nigeria. Ann. Trop Med Parasitol.82:181-184. 
SAHA, S., HASAN, M., KIM, L., FARRAR, J.L., HOSSAIN, B., ISLAM, M., AHMED, A.N.U., AMIN, M.R., HANIF, M., HUSSAIN, M., EL-ARIFEEN, S., WHITNEY C.G. and SAHA, S.K. 2016. Epidemiology and risk factors for pneumonia severity and mortality in Bangladeshi children $<5$ years of age before 10-valent pneumococcal conjugate vaccine introduction. BMC Public Health BMC series. 16: 1233.

SAW, S.M., KOH, D., ADJANI, M.R., WONG, M.L., HONG, C.Y. and LEE, J. 2001. A populationbased prevalence survey of skin diseases in adolescents and adults in rural Sumatra, Indonesia, 1999. Trans Roy Soc Trop Med Hyg. 95: 384-88.

SEDHAIN, P. 2014. Water, Sanitation, Socioeconomic Status and Prevalence of Waterborne Diseases: A Cross-Sectional Study at Makwanpur District, Nepal. Master's thesis in Public Health. Faculty of health sciences / Department of community medicine, University of Tromso. pp. $1-61$.

SHANMUGHAM, C.A.K., ROY, R.G. and GANESAN, A.V. 1977. Kala-azar in Tamil Nadu State during 1945-75 a retrospective and prospective study. Indian J Med Res. 65: 796-806.

SHIDDO, S.A., MOHAMED, A.A., AKUFFO, H.O., MOHAMUD, K.A., HERZI, A.A., HERZI, M.H., HULDT, G., NILSON, L.A., OUCHTERLONY, O. and THORSTENSSON, R. 1995. Visceral Leishmaniasis in Somalia: prevalence of markers of infection and disease manifestations in a village in an endemic area. Trans Roy Soc Trop Med Hyg. 89(4): 361-365.

SIMON, H.2006. Urinary tract Infection in Depth. In depth health articles ADAM, 2006 [on the internet] Review Date: 2006 Jun, Available from http:/ / healthguide.howstuffworks.com/urinary-tract- infection-in-depth.htm.

SMITH, J.L. 2012. http://www.termpaperwarehouse.com/essay-on/Communicable Diseases/84304.

STEINER, T.S., THIELMAN, N.M. and GUERRANT, R.L. 1997. ProtozoalAgent: What Are the Dangers for Public Water Supply? Ann Rev Med.48: 329-340.

SUGUTI, S., TONGU, Y., LNATOMI, S. and PRADHAN, H.D. 1985. A survey on human parasite infections in Nepal. Japanese Journal of Parasitology.34: 285-292.

SUN, J.L., ZHANG, J., MA, H.L. and CHANG, Z.R. 2013. Epidemiological features of typhoid/paratyphoid fever in provinces with high incidence rate and in the whole country, in 2012. Zhonghua Liu Xing Bing Xue Za Zhi.34(12): 1183-8.

TANG, N. and LOU, N.J. 2003. A cross-sectional study of intestinal parasitic infections in a rural district of West China. Can J Infect Dis. 14(3): 159-162.

TANG, J.W., LI, Y., EAMES, I., CHAN, P.K.S. and RIDGWAY, G.L. 2006. Factors involved in the aerosol transmission of infection and control of ventilation in healthcare premises. Journal of Hospital Infection. 64(2): 100-114.

TELLIER, R. 2009. Aerosol transmission of influenza A virus: a review of new studies. Journal of the Royal Society Interface. 6(6): S783-S790.

UDDIN, M.H. and KHANUM, H. 2008. Intestinal parasitic infestation and anaemic status among the adolescent boys in Bangladesh. Univ J Zool Rajshahi Univ.27: 63-65.

WAGENLEHNER, F.M.E., LAIBL, E. and VOGEL, H.K.G.2006. Incidence of nosocomial urinary tract infections on a surgical intensive care unit andimplications for management. Int $J$ Antimicrob Agents. 28: 86-90.

WAN, M.P., SZE-TO, G.N., CHAO, C.Y.H., FANG, L. and MELIKOV, A. 2009. Modeling the fate of expiratory aerosols and the associated infection risk in an aircraft cabin environment. Aerosol Science and Technology. 43: 322-343.

WORLD HEALTH ORGANIZATION / WHO. 1981. Intestinal protozoan and helminthic infection. Switzerland: Tech. Rep. Ser. 666: 18-28.

WORLD HEALTH ORGANIZATION / WHO. 1991. Environmental health in urban development. Tech. Rep. Ser. No. 807, WHO, Geneva.

WORLD HEALTH ORGANIZATION / WHO. 2002. Lymphatic Filariasis: The Disease and Its Control. Technical Report 71: 21-323. 
WORLD HEALTH ORGANIZATION / WHO. 2005. World Malaria Report. WHO, Geneva, Switzerland. pp. 1-35.

YU, Z., ZHAN, J., LI, C.Q. and ZHOU, H.M. 2012. Age and gender analysis of jaundice patients. The Journal of Bioscience and Medicine. 2: 1-3.

ZAMAN, R.F., AWATEF, K.A., KHANUM, H. and AKHTER, T. 2014. Prevalence of dengue fevers among the patients of different economic status attended at local hospital in Dhaka. Bangladesh J Zool.42(2): 161-168.

(Manuscript received on 12 February, 2020 revised on 10 March, 2020) 